Оригинални научни рад

УДК 371.3:821.163.41-1 Мандић С.

373.5.016

Примљен: 30. марта 2021.

Прихваћен: 23. априла 2021.

Нина 3. Говедар ${ }^{1}$

https://doi.org/10.46630/phm.13.2021.55

Универзитет у Бањој Луци ${ }^{2}$

Филолошки факултет

Катедра за србистику

\title{
МОГУЋНОСТИ ПРОУЧАВАЊА ДЈЕЛА СВЕТИСЛАВА МАНДИЋА У НАСТАВИ КЫИЖЕВНОСТИ
}

\begin{abstract}
У раду се бавимо истраживањем оправданости увођења дјела Светислава Мандића у обавезни наставни програм предмета Српски језик и књижевност у гимназијама и средњим стручним школама. Оправданост његовог наставног проучавања поткрепљујемо разматрајући: књижевну вриједност дјела Светислава Мандића; могућност изучавања поезије у контексту Мандићевог живота и стваралаштва у домену сликарске умјетности, те његовог теоријског бављења историјом српске умјетности; могућност корелације са садржајима других предмета, укључујући и предмете који се баве изучавањем природних наука; компаративно тумачење дјела Светислава Мандића у контексту савремене српске књижевности/поезије. Циљ рада је да освијетлимо разлоге зашто поезија Светислава Мандића треба да се нађе у школским програмима и понудимо могуће наставне приступе.
\end{abstract}

Кључне ријечи: Светислав Мандић, поезија, сликарство, методика наставе књижевности, корелативна настава, контекстуално учење, критичко мишљење

\section{Увод}

Пјесничко дјело Светислава Мандића никада није било дио наставних планова и програма за предмет Српски језик и књижевност ни за основне, ни за средње школе и гимназије. На промишљање о томе колики потенцијал његово дјело може да има сагледано у наставном контексту подстакла су нас два увида: 1) важно а занемарено мјесто Светислава Мандића у српској књижевности 20. вијека и 2) недостатак корелацијско-интеграцијског приступања настави књижевности у нашој школској 1 nina.govedar@flf.unibl.org

2 Рад је резултат истраживања у оквиру пројекта Кюижевно-умјетничко дјело и заоставитина Светислава Мандића (Филолошки факултет Универзитета у Бањој Луци). Руководилац пројекта је проф. др Саша Шмуља. 
пракси.

\section{О Светиславу Мандићу}

Светислав Мандић рођен је у Мостару 1921. године, школовао се на Академији ликовних умјетности и радни вијек провео као конзерватор у Галерији фресака у Београду. Његово обимно животно дјело превазилази конзерваторске захвате: био је један од најуспјешнијих фрескокописта, пјесник и истраживач српског средњег вијека. У свим његовим дјелима огледа се извијесна фасцинација нашим средњим вијеком - ликовним представама, записима и траговима које су фрескописци остављали на својим дјелима, настанком и судбином неких од најпознатијих наших манастирских фресака. Осим конзерваторског посла, Мандићев боравак по српским манастирима омогућио му је шире сагледавање контекста настанка и развоја нашег средњовјековног сликарства, утицаја и домета. Предано је и прецизно тумачио историјске прилике и њихове посљедице, те својим истраживањима значајно допринио освјетљавању средњовјековног периода у српској историји. Своја стручна запажања објавио је у неколико књига: Древник, записи конзерватора (1975), Чрте и резе, Фрагменти старог именика (1981), Розета на Ресави (1986), Велика господа све српске земле и други просопографски прилози (1986), Царски син Стефана Немағе, Чиюенице и претпоставке о српском средғовјековль (1990), те кроз чланке у различитим стручним часописима.

Поред стручних и истраживачких интересовања, Мандић је гајио и умјетнички приступ својим темама, који се понајвише огледа у његовом раду на копијама фресака и поезији. Насликао је невелик број умјетничких слика на којима тематизује сличне мотиве као и у својој поезији: Мостар, Београд, манастир Студеницу (ŠMULJA I MARIĆ 2019: 9). Објавио је збирке поезије Двојица (са Велимиром Ковачевићем, 1940), Кад млидијах живети (1952) и Милосно доба (1960), а поезија му је објављена и у два избора: Песме (1990) и Звездара и друге песме (1995). Био је врло цијењен пјесник међу својим савременицима - критичарима и колегама, а као највеће вриједност његове поезије најчешће се издвајају њена интермедијалност и веза са традицијом српског средњег вијека.

\section{Мандић у наставном контексту - зашто и како?}

Са све израженијим напорима да се основно и средњошколско образовање реформише у правцу проблемске и корелацијске наставе, контекстуалног учења и повезивања програмских цјелина из више наставних предмета (види Стратегија (2016) Акциони план (2019)), јавља се и потреба за новим рјешењима у самим програмским садржајима. Да 
би овакав концепт наставе у пракси заживио, у његовом је планирању неопходно програмирати цјелине и наставне јединице које могу да корелирају како на унутарпредметном, тако и на међупредметном нивоу. У том смислу, измјене програмских садржаја у оквиру предмета Српски језик (и књижевност) треба да буду усмјерене на увођење оних садржаја који могу бити доведени у везу не само са предметима попут Историје, Географије, Ликовне и Музичке културе или Вјеронауке, како је то да сада најчешће био случај (због иманентне потребе за временском, просторном или културолошком локализацијом појмова из језика и књижевности), већ и на повезивање са природним наукама и другим гранама умјетности. Што је шири контекст унутар кога ученици усвајају информације, веће су шансе да ће оне прећи у трајно знање (види: ŠVARC 2008: 22-23).

Корелацијска настава ${ }^{3}$ у пракси врло често подразумијева само основно дефинисање заједничких просторно-временских одредница или других очигледних повезница двају појмова на унутарпредметном и међупредметном нивоу, а нешто рјеђе унутар васпитно-образовних подручја ${ }^{4}$. Дубинско проучавање различитих појава, које би ученицима омогућило да откривају везе и сличности између различитих концепата, много је дјелотворније. Оно омогућава ученицима сагледавање „шире слике“ настанка и развоја одређене појаве, разумијевање њене улоге у конкретном историјском и културолошком контексту, те подстиче кри-

3 Ерик Јенсен у својој књизи Супер настава коментарише готово искључиву усмјереност наставних програма на сам садржај уз занемарљиву интердисциплинарност и повезаност са искуственим знањима, која би помогла да се садржаји боље усвоје, док констатује како интердисциплинарни приступ учењу највише одговара учењу у животној реалности (JENSEN 2003). О корелацијској настави у смислу довођења у везу књижевног текста и одговарајућих садржаја из језика, медија и других предмета и предметности које могу помоћи тумачењу текста, Анте Бежен говори у контексту методичких система (BEŽEN 2008: 303). Корелацијско-интеграцијски систем у настави омогућава не само довођење у везу знања из различитих области него и њихово сједињавање у веће сазнајне цјелине које омогућавају контекстуално учење. У својој Методици књижевног одгоја Драгутин Росандић даје својеврсну типологију корелацијског проучавања књижевности у настави. Он се задржава прије свега на односима између умјетности (књижевност, сликарство и музика), те везама које је могуће успоставити на основу међусобних естетских, тематских, мотивских, рецепцијских и других повезаности. На основу категорија које успоставља компаративна естетика издваја: структурну, стваралачку, рецепцијску, историјско-стилску корелацију (2005: 258-261). Такође, Росандић скреће посебну пажњу на књижевне ликове у чијем обликовању умјетност игра значајну улогу, односно ликове умјетника у књижевности.

4 Росандић васпитно-образовна подручја дефинише као „организацијски облик одгојно-образовног сустава који се темељи на повезивању програмских садржаја у јединствене програмске цјелине у њиховој међусобној водоравној и окомитој повезаности и наставне предмете“. Према томе, васпитно-образовно подручје је сустав међусобно повезаних програмских цјелина и наставних предмета, њихових садржаја, методологије, циљева, задаћа и активности у јединствену структуру. (2005: 252). 
тичко размишљање и закључивање. Подстакнути нормама које намећу наставни програми, наставници се најчешће труде да само формално задовоље број часова на којима ће предметност изучавања довести у везу са градивом неког другог предмета који ученици слушају. Међутим, једнако је важно и, свакако, у реалним условима лакше примјењиво, успостављање корелације градива унутар самог предмета. Ово се односи и на међусобну повезаност и условљеност језика и књижевности (а самим тим и њиховог проучавања), али и на међусобне односе различитих појмова и појава који се изучавају у оквиру једне наставне области (књижевност, језик и језичка култура).

Интермедијални приступ књижевном дјелу у настави ${ }^{5}$ подразумијева примјену увида из више различитих умјетности или изучавање више предметности које произилазе из различитих умјетности. Свакако су најзаступљенији приступи коју у везу доводе књижевност и ликовну, музичку, позоришну или филмску умјетност. На основу оваквих паралела ученици не само да учвршћују знања о специфичним поетикама, стилским формацијама, теоријским постулатима појединих умјетности него им, доводећи у корелацију знања и увиде из више области, омогућавамо свеобухватне и сједињавајуће увиде.

На сличан начин, богато и мултимедијално дјело Светислава Мандића може нам помоћи да остваримо бројне наставне циљеве и контекстуализујемо једну велику тему у српској историји. Наиме, Мандићева животна преокупација и његово занимање су дјелатности које данас не добијају много пажње јавности и врло је вјероватно да се ученици, чак ни у средњој школи, нису сусрели са терминима конзерватор или кописта (фресака). А управо су то занимања која су од изузетне важности за очување наше историјске баштине. Кроз упознавање са Мандићевим животом, ученицима се може скренути пажња на различите начине очувања баштине, традиције и културних добара једног народа, те на неопходност постојања културне политике која је у складу са циљевима очувања културног насљеђа. Настава књижевности, иако јој то није примарни циљ, треба да се бави и подизањем културне свијести и информисаности ученика, и да им пружи увид у то колико је култура свеобухватан појам, иако је сачињава однос према различитим умјетностима. Други важан задатак који настава књижевности треба да оствари, а живот и рад Светислава Мандића могу бити добар примјер и у том аспекту, јесте разумијевање односа између различитих грана умјетности и увиђање како исте или сличне поетике функционишу у различитим медијима. Мандић се и у сликарству и у поезији врло често бавио сличним мотивима, што

5 О могућностима примјене интермедијалног приступа у настави књижевности више види у: (GOVEDAR 2017: 233-245). 
нам открива неку врсту умјетничке преокупације, на првом мјесту, али и поетичке оријентације.

\section{Поезија Светислава Мандића у настави}

Иако је иза себе оставио обимом невелико дјело, Светислав Мандић често је перципиран од стране критике и колега по перу као један од великих пјесника свога времена. Критика се најчешће освртала на три главне особине Мандићеве поезије: меланхоличну лиричност, питорескност и историчност. Тако, на примјер, Вељко Радовић пише: „[М]андићевим колоритним и 'ароматичним' песмама у молском тону складно се разливају и уливају једна у другу боје хармонично успостављеног ликовног редоследа и доживљаја света као унутрашњег пејзажа“ (RADOVIĆ 1996: 958). Оно што је изнад свега одлика Мандићеве поезије јесте њена интермедијалност која се очитава у различитим релацијама. Саша Шмуља и Андреја Марић дијеле их у својој студији на пјесме „а) надахнуте самим сликарством, б) које пјевају о неком сликарском умјетничком дјелу или пак о сликару, в) које садрже пјесникове констатације о сликарству као елементу умјетничке теорије односно аутопоетике, г) које дијеле заједничке теме са сликарским дјелима, д) које утичу на читаочеву визуелну перцепцију, односно визуелизацију текста итд.“ (2019: 137). Управо захваљујући широкој палети појавних облика у којима се интермедијалност у њој испољава, Мандићева поезија нам омогућава остваривање наставних циљева које обрађујући друга књижевна дјела не можемо увијек у потпуности да испунимо.

Један од циљева проучавања Мандићеве поезије могао би се односити управо на проналажење елемената интермедијалности, односно, препознавање уплива елемената ликовне умјетности у његову поезију. То води разговору не само о повезаности Мандићеве поезије и ликовног стваралаштва него и о вези између двије умјетности, уопште. Са старијим ученцима може се разговарати о томе које поетичке елементе дијеле поезија и сликарство романтизма, модернизма, надреализма итд. На тај начин проширујемо њихово познавање теорије и историје умјетности, развијамо моћ опажања и закључивања, учимо их контекстуализовању, разумијевању утицаја специфичних друштвено-историјских околности на настанак умјетничких дјела, подстичемо да увиђају сличност функције различитих поступака и метода у различитим умјетностима (облик стиха у пјесми, потез кистом на слици, ритмичке партије у музичком комаду). Све ово води усвајању комплексних компетенција које су у вези са доживљајем и разумијевањем различитих форми умјетничког израза, а које у исто вријеме и проширују и продубљују ученичке читалачке 
компетенције. ${ }^{6}$ Како нас сама књижевност богати различитим сазнањима и доживљајима, тако би и циљ наставе књижевности, између осталог, требало да буде богаћење ученичког искуства у сусрету са различитим умјетничким дјелима. Поготово онда када нам само књижевно дјело намеће још један вид умјетности кроз актуелизоване мотиве, стилске поступке, тематске преокупације и томе слично.

Овакву прилику пружа нам не само поезија Светислава Мандића, а посебно неке од његових понајбољих пјесама, него и његови есеји и стручни записи о ликовним представама из наше старине. Тако, на примјер, његов чувени есеј „Симонидине очи“ може значајно да допринесе проширивању ученичких спознаја у вези са фреском коју у својој пјесми тематизује и Милан Ракић - значају Ракићеве пјесме за очување сјећања на немиле историјске догађаје, као и ширину сфере утицаја коју једно књижевно дјело може да има. Ако ће ученици на основу Ракићеве пјесме сазнати нешто о конкретном историјском догађају, Мандићев есеј може да им пружи шири контекст сагледавања утицаја који умјетност може да има и двосмјерност тог утицаја (Ракић својом пјесмом додатно даје на значају конкретној фресци, подижући тако њен културни, симболички и материјални значај, а Мандићев есеј истиче комплексност питања обнове фреске које је условљено примарно Ракићевом пјесмом - Ракићева пјесма настаје „од фреске“, судбина фреске зависи од Ракићеве пјесме). О Мандићевим пјесмама које тематизују теме из прошлости, Никола Кољевић каже да је у њима успио „из пепела прошлости да васкрсне лепоту која траје у свести иако је нестало оно из чега је никла у животу“ (KOLJEVIĆ 1991: 68). Истраживање љепота које је Мандић на овај начин обновио може, такође, да буде предмет ученичког истраживања, између осталог и јер је, како наводи Бранко В. Радичевић: „На његово стваралаштво утицао [je] и специфични положај у коме се налазио, бављење по манастирима где копира и конзервира старе фреске“ (1956). Овако широкој и комплексној теми поетике и мотивске преокупације једног свестраног умјетника најбоље је приступити кроз проблемску наставу, при чему свака група ученика има задатак да се бави једним специфичним доменом живота и стваралаштва Светислава Мандића, те интертекстуалним и интермедијалним везама које је могуће успоставити у вези са 6 У Наставном плану и програму за Српски језик (НПП 2020) у сваком разреду као један од исхода проучавања књижевности наводи се могућност компаративног сагледавања књижевних и других умјетничких дјела. С тим у вези, међу наставним садржајима увијек се нађу препоруке и задаци који укључују одлазак ученика у позориште или биокоп (гледање представе, односно филма), укључивање музичких садржаја који могу да се доведу у везу са проучаваним дјелом у наставу итд. Све ове активности немају за циљ само упознавање ученика са различитим умјетничким медијима којима се актуелизуује исти сиже или мотив него, управо, и развијање компетенција неопходних за комплексно доживљаавање и разумијевање различитих умјетничких израза. 
његовим стваралаштвом. У практичном смислу говорећи: док се једни ученици баве анализом појединачних пјесама, други Мандићевим сликарским и конзерваторским радом, трећа група може да истражује његове књиге Древник и Чрте и резе како би открили које то историјске и поетске теме корелирају са Мандићевим интересовањима у осталим областима његовог стварања.

За анализу у средњим стручним школама и гимназији посебно су интересантне Мандићеве пјесме Рашки сликар, Сликар и трепереюе боја у простору и Ноћ у Сопоћанима.

Пјесма „Рашки сликар“ тематизује мистерију настанка умјетничког дјела - фреске, коју лирски субјект посматра.

Пред иркву и реку станем, па заћутим, и мислим, да л' умре млад тај човек, ко Ђорђоне, ил прастар као Тицијан?

Можда га заволела немағићка, висока и млада, обесна и мудра попут очева, и рекла му једне ноћи борове, понеко дивно слово љубве, велмочко.

И после он преточио юене очи, и руке, у богородичин лик, нежан, и помало тубичаст, и као пролећан, па се једној тьудској тьубави клағали старовлашки чобани и часни јереји златних одежди.

А он дуго носио иарским путевима од Ибра до Солуна један мили лик, ко амајлију. Сад, кад све је прах, и све је тако свето, пред иркву и реку станем, па заћутим, и мислим да л умре млад тај човек, ко Ђорђоне, ил стар и грешан као Тищијан?

Његове мисли одводе га вијековима у прошлост, запитаног над животом и судбином аутора дјела које он данас посматра патинирано. Алузија на Ђорђонеа и Тицијана у првој строфи и довођење у везу судби- 
не непознатог умјетника са великим именима високе италијанске ренесансе двоструко је значајна: на првом мјесту доводи његово дјело у везу са дјелима највећих ренесансних умјетника, чиме одаје субјективни доживљај вриједности ликовне представе у коју гледа, умјешност њене техничке изведбе и нуди нам неке параметре (у складу са поетиком периода) према којима можемо да претпоставимо како изгледа богородичин лик у који је лирски субјекат загледан. Додатну потврду „ренесансног“ у фресци коју посматра добијамо у трећој строфи, кроз стих у коме се о насликаном лику каже да је „нежан, и помало љубичаст, и као пролећан“, што је у складу са основним поетичким одликама ренесансног сликарства. Други значајан траг на који нас ова алузија наводи односи се на умијеће самог умјетника - његово поређење са великанима италијанске ренесансе може да се тумачи и као потреба да се анонимном средњовјековном фрескописцу ода почаст због његовог умијећа и стила који је раван највећима (и најславнијима) у историји сликарства.

О његовој судбини лирски субјекат промишља у складу са оним што му сугерише сопствени доживљај лика са фреске. Богоридичин лик „нежан, и помало љубичаст, и као пролећан“, што је необично романтизована представа богомајке, лирском субјекту сугерише да се иза обриса њеног лика крије лице које је фрескописац познавао - можда лице младе Немањићке. И ова алузија на неку врсту тајне и скривене љубави између умјетника и младе велмошкиње коју красе најплеменитије особине њених предака, сугерише двоструко значење: вјеру у нераскидиву везу између искуства умјетника и његовог умјетничког израза, и, на другом мјесту, својеврсну специфичност поимања узајамности и нераскидивости световног и духовног које лирски субјекат на овај начин изражава. Готово иронично, он излаже идеју о фрескописцу који свети лик гради према лику племкиње у коју се загледао, показујући како чак и најсветије ствари којима се клањамо, у својој суштини, оличавају слабост и крхкост човјекову које произилазе из страсти и потребе. Тако се том лику миле племкиње, и не слутећи, клањају и чобани и високо свештенство. У прилог оваквом тумачењу говори и стих „Сад, кад све је прах, и све је тако свето“ којим се сугерише да је тек сада, вијековима касније, тек када је прошлост дјелом времена претворена у прах (што значи да не може самостално да посвједочи) постало „све свето“ - дакле, и оно што у датом тренутку у прошлости то није било.

„Сликар и треперење боја у простору“

Ако би питали: ита је вечно?

Ја бих рекао: боја. 
Јер све је било, све се меньа, остају само mpenepersa

што допиру до нашег вида са неба, ивећа, воде, зида,

дајући боју и имена

свему на свету, од правремена.

И када једном све се згроми, и буде прашина, атоми,

mpenepuћe jou od toux бoje за очи које не постоје.

Ако ме питају: вечно што је? одговорићу: то су боје.

И ја, што гледам ко у снима, $u$, луд за сликом, не знам за се,

постајем једнак боговима, кроз мене вечност прелама се.

Ова Мандићева пјесма може да буде интересантна за проучавање са више аспеката и, самим тим, указивање ученицима на различите могуће приступе књижевним текстовима и функцију квалитетног синтетизовања закључака до којих се дошло. На асоцијативном плану, пјесма „Сликар и треперење боја у простору“ ученике може да подсјети на Попину „Манасију“. У објема пјесмама доминантан је мотив боје. Значај и симболика који им се дају врло су наглашени и у једној и у другој пјесми - код Попе су то конкретне боје као симбол византијске хришћанске традиције и вјере у однос са Богом и могућност спасења кроз дјело које се ствара, а код Мандића као принцип уздизања ствараоца изнад овоземаљског и пролазног. Оба лирска субјекта су у улози сликара/фрескописца и обојица поистовјећују боје и своје стваралаштво са искуством вјечног живота: „постајем једнак боговима, / кроз мене вечност прелама се“ (Мандић) и „Златно и плаво / Последња звезда у души / Последњи бескрај у оку“ (Попа).

Са друге стране, Мандићева пјесма може да буде подстицај за довођење у везу предметности књижевног дјела и природних наука. Лир- 
ски субјекат у пјесми „Сликар и треперење боја у простору“ не говори само о субјективном и духовном доживљају боја. Он говори и о научном, физичком аспекту реализације боја у материјалном простору - говори о њиховој трајности и треперењу, односно, вибрацији свјетлосних таласа као начину њиховог настанка. Такође, он спомиње потпуни распад свега материјалног што нас окружује на ниво атома и тврди да ће и тада од свега остати само боје. Будући да пјесник користи доказана научна сазнања у свом дјелу, може бити функционално ученицима указати на то како исту материју обрађују научни или научно-популарни текстови са једне, и умјетнички са друге стране. Ова врста компарације може послужити и као увод у разговор о томе постоје ли „неумјетничке“ теме, односно шта је то што сваки мотив и сваку тему, ма колико она непоетична у нашем свакодневном искуству била, може претворити у врхунско умјетничко дјело. На тај начин код ученика се на практичним примјерима развија свијест о разликама између књижевних и некњижевних врста, али и о реалистичном и романтизованом погледу на свијет, односно значају перспективе из које појаве посматрамо. У вези са тематизовањем универзалних питања и великих идеја људског рода о којима се једнако пише и у науци и у књижевности и о којима једнако интензивно промишљају и пјесници и научници, можемо се задржати на феномену треперења. Мандић „треперење боја“ додатно поетизује, па тај његов израз осим физичког елемента дјеловања таласа из видљивог спектра семантизује и треперење као титрај, као постојање у одјеку - одјеку који допире из прошлости (баштина) и који ће опстати и онда када од наше данашње реалности остану само честице (насљеђе за будућност). Са друге стране, један од највећих научника 20. вијека, Никола Тесла, врло се интензивно бавио проучавањем вибрација, односно утицајем фреквенција на свијет око нас (види: TESLA 2006). Истраживање ове теме за ученике може бити вишеструко корисно и у вези са неким другим предметима, али и као процес освјешћивања тога како се универзална животна питања тематизују у различитим областима човјековог стварања ${ }^{8}$.

7 Ученичко интересовање за ову тему могу привући бројни публицистички и научнопопуларни текстови. С једне стране може бити интересантно упознати их са чињеницом да је феноменом боја био фасциниран до те мјере да је развио и сопствену теорију и објавио је под називом Учене о бојама велики њемачки романтичар Јохан Волфганг Гете, кога они познају, прије свега, као књижевног дјелатника. Другачију врсту информација о споју умјетности и физике кроз историју доноси, на примјер, чланак Физика и уметност: Тајна ренесансног ирвеног објављен у недјељнику Време (2003), доступан на [https://www.vreme.com/cms/view.php?id=347017].

8 Овдје није згорег напомеути да оваква тема може да буде вишеструко корисна и за развијање критичког и дивергентног мишљења код ученика. Теслино изучавање вибрација посљедњих година привлачи велику пажњу различитих стручњака, али и бројних лаика који своја запажања и разумијевања његових теорија представљају на свјетској 
Наративна пјесма „Ноћ у Сопоћанима“ тематски се дјелимично подудара са прве двије споменуте пјесме. Њу чине мотиви везани за свакодневни живот сељака и радника у околини манастира Сопоћани у коме лирски субјекат борави сликајући фреске. За потребе илустровања идеје иза овог рада, на овом мјесту ћемо скицирати могући приступ неколиким интерсантним мотивима које Мандић тематизује у овој пјесми.

То је на првом мјесту свакако питање односа према културном, односно црквеном насљеђу, са којим смо се сусрели и у друге двије пјесме. У првој строфи Мандић овдје актуелизује питање оригиналног творца фресака које он сада рестаурира и у њему препознаје руку коју упорећује са Божијом. У том односу не препознајемо само Мандићево хришћанско увјерење о божанском надахнућу које се реализује кроз посвећеног ствараоца него и мисао о умјетности и њеном поријеклу уопште, односно о изворима надахнућа. На сличном су трагу грађени и стихови који говоре о умјетниковој опсједнутости „чаролијом слика у цркви под брдом“. Он жели да говори о њиховој чудесности, али сумња да би му ико вјеровао да „ко их гледа анђелска му крила расту“. И ови стихови служе као потврда оба увјерења: да је црквена умјетност есенција вјеровања и хришћанског доживљаја, да кроз фрескописца проговара Бог сам, те да је извор умјетничког надахнућа нигдје друго него у самом Богу. У старим црквама, каже се, свака је слика мила „јер у себи чува дар и страх Божји“. „Ноћ у Сопоћанима“ врло живо и реалистично дочарава не само сопоћански пејзаж у сумрак него и живи разговор који крај будуће хидроцентрале воде уморни радници. Њихова карактеризација дата је у свега неколико стихова, али стожерне вриједности које овај колективни лик носи јесу традиција и насљеђе. Они свој вечерњи хљеб ломе пажљиво и побожно, у сладу са обичајима предака; наздрављају онако како је „ред од памтивека“, позивајући се на случај најмлађег брата Југовића (Бошка); кад удају кћер срећни су што је мираз добар и кућа у коју одлази домаћинска; говорећи о нечијем брату - свјетском путнику - истиче се да, поред свега што је видио у свијету, у земљама гдје никад није зима и гдје људи једу само воће, свега има - али нема наших шљива ранки и наших крушака караманки. Кад мајстори долазе да руше стари да би поставили нови кров (као симбол напретка и промјена и на ширем, друштвеном плану), на јаворовој грани ће завијорити нове кошуље у име старих обичаја и традиција. По растанку сељаци се још дуго дозивају и чују се попијевке, јер је вјеровање о вампирима који ноћу бораве на раскршћима још увијек врло живо у народној свијести.

Осим изразитих хришћанских, са једне, и фолклорних мотива са мрежи. Због тога, ученицима може бити посебан изазов доћи до релевантних информација у вези са овом темом, чиме вјежбају критичко мишљење, логичко закључивање, медијску писменост и сналажење у дигиталном простору. 
друге стране, пажњу у пјесми привлачи и неколико конкретних стихова другачије провинијенције. На првом мјесту бисмо скренули пажњу на парафразу темељног концепта Хераклитове филозофије - Panta rei - у стиху „ништа на свету не догађа се двапут истоветно“, као примјер својеврсне идејне синергије у погледу на свијет, погледу који не мора бити нужно означен или омеђен само једним увјерењем, једним концептом или једном филозофијом. Друга је осврт на аутопоетички исказ о пјесми коју лирски субјекат жели да испјева у том тренутку, о муци немогућности да лијепо „слаже ријечи“ и, коначно, поетичку констатацију да се „без муке [се] песма не испева“.

Компарација - Мандић, Попа, Црњански и други

Значајно је, такође, као својеврсну синтезу, скренути ученицима пажњу на то да Мандић није једини наш сликар који се прославио и као пјесник. Ученици су се раније већ срели са дјелом Ђуре Јакшића и упознали са чињеницом да је и овај наш велики пјесник романтизма по звању и образовању био првенствено сликар. Стога би квалитетно усмјерено упоредно проучавање поетских и сликарских мотива код ова два пјесника и сликара такође могло ученике довести до важних закључака о поетици, мотивима који се понављају у оба медија и код једног и код другог, разумијевању различитих облика стваралачког израза и, на концу, сагледавања историје српске умјетности у једном другачијем контексту.

Друга могућост компаративног приступа произилази из поетичких сличности Мандића са другим пјесницима, које су многи критичари препознавали. Драшко Ређеп у његовој поезији препознаје лексику Црњанског, Радичевићеву сентименталност и романтичарски болећиву чежњивост (REĐEP 1961a: 511-512), али и тематску сличност са Васком Попом и Дејаном Медаковићем који су „толико опсесивно и драматично исцелитељски ликовни атлас наше баштине сугерисали као једну од оних истина које се не доказују него које јесу“ (REĐEP 1961b: 1960).

Петар Марјановић у једном свом раду посебно наглашава све оно што суштински раздваја Црњанског и Мандића, узгред свим сличностима који су многи аутори истицали: Црњански је револуционаран, Мандић је личан; Црњански „самоуверен до нарцисоидности“, а Мандић „скроман до смерности“; Црњански „светски дух“, Мандић омеђен „нашим брдима и прошлошћу његовог народа“ (MARJANOVIĆ 1966: 309). Слично поступа и Драган Недељковић поредећи га са Попом: „Попа је модеран [...], Мандић је изронио из традиције“, „Попа се уздиже до општости, а Мандић је националан“, Мандић је конкретнији, Попа „надмоћнији и интелектуалнији“ (NEDELJKOVIĆ 1961: 75).

Будући да су ово све ученицима позната имена и дјела, они ће 
врло лако доћи до примјера у дјелима једних и других који ће поткријепити ове исказе, али ће у исто вријеме имати прилику да самостално упореде дјела и да изнесу своја запажања о потенцијалним сличностима или разликама које код одабраних пјесника уочавају. На овај начин ученици не само да јачају своје читалачке компетенције него и развијају критички дух и способност да самостално закључују и аргументују своје ставове, посебно уколико се они не поклапају са ставовима критике који су им понуђени. Како би ученици развијали сопствене могућности тумачења и разумијевања књижевних дјела важно је омогућити им да изнесу своја запажања, али и стално их усмјеравати на то да своје ставове, мишљења и увјерења поткрепљују примјерима из књижевних дјела, стручне литературе, свог ранијег читалачког искуства итд. Тиме се код ученика подстиче и потреба за додатним истраживањем, али и за његовањем културе дијалога, уважавањем туђих мишљења и поткрепљивањем сопствених.

Због свега наведеног, али и бројних разлога које нисмо експлицирали у овом раду, вјерујемо да би проучавање поезије Светислава Мандића, прије свега, али и његовог сликарског и теоријског рада представљало значајну и функционалну допуну наставног програма за гимназије и средње стручне школе.

\section{Цитирана литература}

AKCIONI PLAN 2019: Akcioni plan sprovođenja reformskih procesa u oblasti predškolskog, osnovnog i srednjeg vaspitanja I obrazovanja u Republici Srpskoj. https://www.vladars.net/sr-SP-Cyrl/Vlada/Ministarstva/ mpk. 26. 12. 2020. Акциони план спровођења реформских процеса у области предшколског, основног и средњег васпитања и образовања у Републици Српској. https://www.vladars.net/sr-SP-Cyrl/Vlada/Ministarstva/mpk. 26. 12. 2020.

BEŽEN 2008: BEŽEN, Ante. Metodika, znanost o poučavanju nastavnog predmeta. Zagreb: Profil, 2008.

GOVEDAR 2017: GOVEDAR, Nina. „Od Alije Đerzeleza do Mustafe Madžara. Intermedijalna sintetizacija likova“. Filolog, br. 16 (2017), str.: 233-245. [orig.] „Од Алије Ђерзелеза до Мустафе Маџара. Интермедијална синтетизација ликова“. Филолог, бр. 16 (2017), стр. 233-245.

JENSEN 2003: JENSEN, Eric. Super-nastava. Nastavne strategije za kvalitetnu školu $i$ uspješno učenje. Zagreb: Educa, 2003.

KOLJEVIĆ 1991: KOLJEVIĆ, Nikola. Poezija (1945-1980): Pesnici lirske akcije. Sarajevo: Svjetlost, 1991. [orig.] КОљЕВИЋ, Никола. Поезија (1945-1980): Песници тирске акиије. Сарајево: Свјетлост, 1991

MARJANOVIĆ 1966: MARJANOVIĆ, Petar „Otići ili ostati: zapis o poeziji Svetislava Mandića“. Savremenik, knj. 24 (decembar 1966): 304-312.

NEDELJKOVIĆ 1961: NEDELJKOVIĆ, Dragan. „Svetislav Mandić, Milosno doba“. 
Putevi, br. 1 (juli 1961). Banja Luka: Novi glas, str. 72-75.

RADIČEVIĆ 1956: RADIČEVIĆ, Branko V. “Dva žuđenja: slikarstvo i poezija”, razgovor sa Svetislavom Mandićem. Duga, broj 542. godina 12 (22. April 1956). Beograd: BIGZ, 1956. [orig.] РАДИЧЕВИЋ, Бранко В. “Два жуђења: сликарство и поезија”, разговор са Светиславом Мандићем. Дуга, број 542. година 12 (22. Април 1956). Београд: БИГЗ. 1956.

RADOVIĆ 1996: RADOVIĆ, Veljko. „Posvećeni obični trenuci“. Letopis Matice Srpske, knj. 458, sv. 6 (decembar 1996): str. 957-959. [orig.] РАДОВИЋ, Вељко. „Посвећени обични тренуци“. Летопис Матице српске, књ. 458, св. 6 (децембар 1996): стр. 957-959.

REĐEP 1961a: REĐEP, Draško. „Svetislav Mandić: Milosno doba“. Letopis Matice srpske, knj. 386, sv. 6 (1961), str. 511-512. [orig.] РЕЂЕП, Драшко. „Светислав Мандић: Милосно доба“. Летопис Матице српске, књ. 386, св. 6 (1961), стр. 511-512.

REĐEP 1961b: REĐEP, Draško. Književnost, knj. 104, sv. 11/12 (1961), str. 1960-1962. [orig.] РЕЂЕП, Драшко. Књижевност, књ. 104, св. 11/12 (1961), стр. 1960-1962.

ROSANDIĆ 2005: ROSANDIĆ, Dragutin. Metodika književnoga odgoja. Zagreb: Školska knjiga, 2005.

STRATEGIJA 2016: Strategija razvoja obrazovanja Republike Srpske za period 20162021. godine. https://www.vladars.net/sr-SP-Cyrl/Vlada/Ministarstva/mpk. 26. 12. 2020. [orig.] Стратегија развоја образована Републике Српске за период 2016-2021. године. https://www.vladars.net/sr-SP-Cyrl/Vlada/ Ministarstva/mpk/. 26. 12. 2020.

ŠMULJA I MARIĆ 2019: ŠMULJA, Saša i Andreja MARIĆ. Toke od meesečine: poezija i eseji Svetislava Mandića. Banja Luka: Centar za srpske studije, 2019. [orig.] ШМУљА, Саша и Андреја МАРИЋ. Токе од меесечине: поезија и есеји Светислава Мандића. Бања Лука: Центар за српске студије, 2019.

ŠVARC 2008: SCHWARZ, Daniel R. In defense of reading: teaching literature in twentyfirst century. Chichester: Wiley-Blackwell. 2008.

TESLA 2006: TESLA, Nikola. Članci. Beograd: Zavod za udžbenike i nastavna sredstva, 2006. [orig.] ТЕСЛА, Никола. Чланци. Београд: Завод за уџбенике и наставна средства, 2006. 
Nina Govedar

\section{POTENTIALITY OF STUDYING SVETISLAV MANDIC'S WORK IN LITERATURE TEACHING}

In this paper we discussed some features of Svetislav Mandićs poetry that can be observed in specific ways in literature classes. Namely, the specificity of this poet is reflected in his multiple creative identities. The fact that he was a painter, that is, a copyist, by education, gives us an unusual view of (auto)poetic features of his poetry in a comparative way. Also, his work on art history, research of old works of art and stays in medieval monasteries contributed to an excellent knowledge of the culture and traditions of our Middle Ages, which in the classroom can be important as a starting point for comparative and correlative perception of Serbian medieval art. Finally, the comparative approach that puts Mandićs work in the context of contemporary Serbian poetry of the 20th century, but also the tradition of Orthodox spirituality in Serbian poetry can be as important.

Keywords: Svetislav Mandić, poetry, painting, methodology of teaching literature, methods of teaching literature, correlative teaching, contextual learning, critical thinking 